Selcuk Journal of Agriculture and Food Sciences

$\underline{\text { http://sjafs.selcuk.edu.tr/sjafs/index }}$

Research Article
SJAFS

(2020) 34 (3), 183-188

e-ISSN: $2458-8377$

DOI:10.15316/SJAFS.2020.214

\title{
The Effect of Heat Stress on Milk Yield, Milk Fat Rate and Rectal Temperature in Holstein-Friesian Dairy Cattle
}

\author{
Mustafa KİBAR ${ }^{1 *}$, DGalip BAKIR², (D) Ayhan YILMAZ ${ }^{3}$
}

${ }^{1}$ Selcuk University, Faculty of Agriculture, Department of Animal Sciences, Konya, Turkey

${ }^{2}$ Kahramanmaraş Sütçü İmam University, Faculty of Agriculture, Department of Animal Sciences, Kahramanmaraş, Turkey

${ }^{3}$ Siirt University, Faculty of Agriculture, Department of Animal Sciences, Siirt, Turkey

\begin{tabular}{l}
\hline ARTICLE INFO \\
\hline Article history: \\
Received date: 04.07 .2020 \\
Accepted date: 28.08 .2020 \\
\hline Edited by: \\
İbrahim AYTEKIN; Selcuk University, \\
Turkey \\
\hline
\end{tabular}

Keywords:

Heat stress

Holstein-Friesian

Milk yield and content

Rectal temperature

\begin{abstract}
Heat stress is an environmental factor that negatively affects the morphological and physiological properties of dairy cattle. The aim of this study is to investigate the relationship between heat stress and milk yield, milk fat ratio and body temperature in Holstein-Friesian dairy cattle. The data of the study was obtained from a private Kurtalan Farm of Siirt province, the Southeastern Anatolia Region of Turkey. Milk yield and other traits of 13 head HolsteinFriesian dairy cattle were recorded in March, April, May, June, July, August and September. In addition, temperature and humidity records were recorded in the farm and in the parlor to be used for calculating the temperature humidity index value. In the analysis of data, correlation and regression methods were used. As a result of the study, the negative correlation $(\mathrm{P}<0.01)$ was found between milk yield and milk fat ratio and the positive correlation $(\mathrm{P}<0.001)$ were detected between heat stress and body temperature. In addition, a significant negative relationship was observed between rectal temperature and milk yield $(\mathrm{P}<0.01)$.
\end{abstract}

\section{Introduction}

Animal husbandry is important in terms of adequate and balanced nutrition of people and consumption of animal-derived proteins such as meat, milk and eggs that determine the level of development of countries (Hekimoğlu and Altındeğer, 2008). In order to meet the needs of the increasing world population such as meat and milk, the productivity per animal needs to be increased. Factors affecting the productivity of animals are examined under two main headings as genetics and environmental factors (Tuncel, 1994). Among environmental factors, care, feeding and climate factors come to the fore. Although temperature, humidity and wind come to the fore among the climate factors, it is seen as the most important factor since the temperature factor affects the productivity of the animals negatively (Mutaf and Sönmez, 1994; Öten et al., 2010). When the temperature occurred by the ambient temperature and humidity values (Thom, 1959) exceeds the humidity index threshold values, the animals are exposed to heat stress. Studies have reported that heat stress begins when the temperature humidity index value exceeds 65 and mortality rates increase when it exceeds 80 (Vitali et al., 2009; Collier et al., 2011). Many studies have been conducted to show that the heat stress negatively affects milk yield (West, 1999; West et al., 2003; Brouček et al., 2009; Baumgard et al., 2012; Brown et al., 2015; Al Reyad et al., 2016; Trajchev et al., 2016; Zhu et al., 2016) and milk fat rate (Arieli et al., 2004; Rejeb et al., 2012; Brouček et al., 2009; Ghavi Hossein-Zadeh, 2013). However, studies reporting that heat stress negatively affects the reproductive characteristics of animals have also been conducted (Evans et al., 2010; Khodaei-Motlagh et al., 2011; ElWishy, 2013).This study aimed to investigate the effect of heat stress on milk yield, milk fat ratio and body temperature in Holstein-Friesian dairy cattle.

\footnotetext{
*Corresponding author email: mustafa.kibar@selcuk.edu.tr
} 


\section{Materials and Methods}

This study was carried out in a private Agricultural Enterprise located in Gökdoğan village of Kurtalan district of Siirt province. The enterprise is located in the Southeastern Anatolia Region, where the continental climate prevails and the temperatures can rise $42{ }^{\circ} \mathrm{C}$ in August (Figure 1). The animals are housed in semi-open shelters (Figure 2).

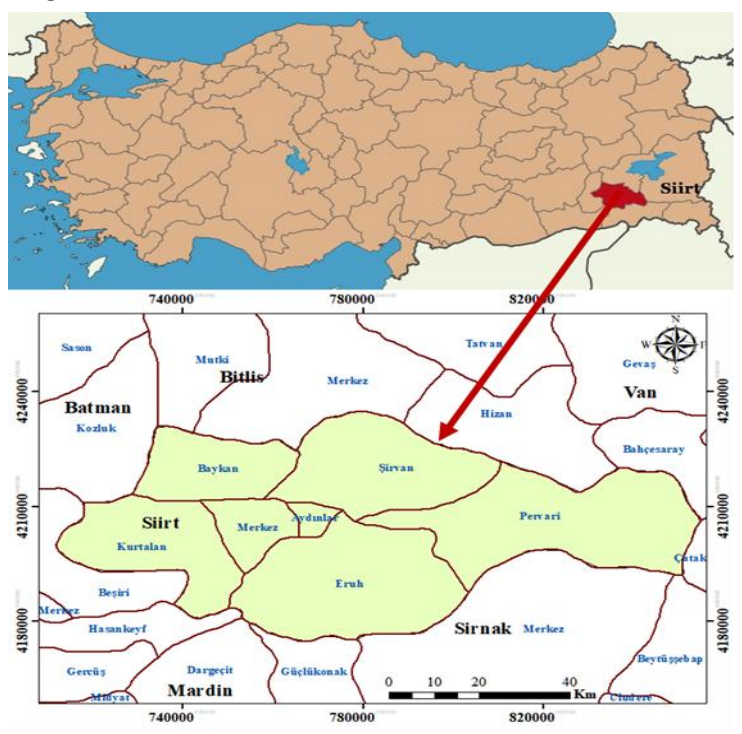

Figure 1

Geographical location of Siirt province

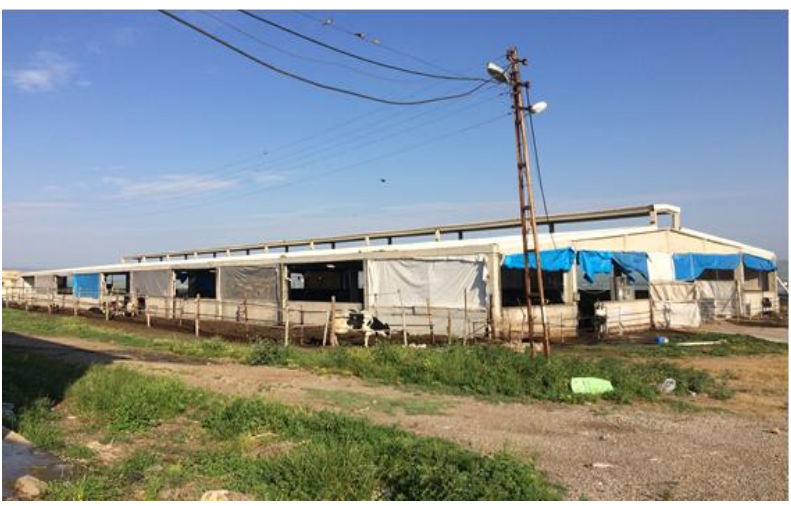

Figure 2

Business where the study is carried out

Feeding is done two times a day after morning and evening milking. Milking is done automatically between 05:00-07:00 in the morning and 17:0019:00 in the evening. $21 \mathrm{~kg}$ corn silage, $10 \mathrm{~kg}$ concentrate and $3 \mathrm{~kg}$ wheat straw are given per animal. In addition, when corn harvest is made, wheat straw is halved and $1.5 \mathrm{~kg}$ corn straw is used instead. The feedstuffs used were analyzed for dry matter (DM), crude protein (CP), crude fat (CF), crude ash (CA), acid detergent cellulose (ADC) and neutral detergent cellulose (NDC) (Table:1)
Table 1

Nutrient content of feeds used for farm

\begin{tabular}{lllllll}
\hline Nutrient contents, \% & DM & CP & CF & CA & ADC & NDC \\
\hline Corn straw & 91.18 & 3.05 & 1.29 & 6.57 & 54.14 & 75.05 \\
Wheat straw & 92.61 & 2.84 & 1.40 & 6.32 & 57.39 & 74.23 \\
Corn silage & 95.05 & 4.90 & 1.61 & 7.92 & 34.93 & 61.21 \\
Concentrated feed & 88.61 & 18.01 & 4.26 & 7.94 & 9.17 & 27.48 \\
\hline
\end{tabular}

In determining the cattle, the calving date and milk yields of the cows were taken into account. Because there are no farms in Siirt province that uses herd management program or support academic studies, 13 animals were used in the current study. Accordingly, study started with 9 animals giving birth in March and 4 animals giving birth in April. Three of these animals were first, five of these animals were second twoof these animals were third, one of these animals was forth and two ot these animals were seventh lactation. The selected animals were kept with other animals and no different treatment was made. Samples collecting were started in a week after birth in order to lose the effect of colostrum milk and continued from March to September. Milking was performed with an individual milking machine, milk samples were taken and milk yield was recorded. After milking, the rectal temperatures of the animals were measured with a thermometer. During milking, environmental temperature and humidity values were recorded with a temperature and humidity recorder. The milk samples were analyzed immediately on the milk analyzer.The temperature and humidity recorder placed in an area where the animals spend the most time in the shelter and where the sun does not directly contact, the environmental temperature and humidity values were recorded every two hours. In calculating the temperature and humidity index (THI) in the shelter and in the parlorthe Formula (1)

$\mathrm{THI}=(0.8 * \mathrm{Tdb})+((\mathrm{RH} / 100) *(\mathrm{Tdb}-14.4))$ +46.4 (1) was used (Mader et al 2006).

For statistical analysis, milk yield and milk fat ratio were selected as dependent variable, months, lactation number, rectal temperature and temperature humidity index values were evaluated as independent variables. Also rectal temperature was evaluated as dependent variable. Since the measurements are in a longitudinal (repetitive) structure obtained at 7 different time points for each animal, analyzes have been carried out in a linear fixed-effect mixed model structure that takes into account repeated measurements.

\subsection{Model}

$\mathrm{Y}_{\mathrm{ijkl}}=\mu+\mathrm{a}_{\mathrm{i}}+\mathrm{b}_{\mathrm{j}}+\mathrm{b}_{1}\left(\mathrm{x}_{\mathrm{ijkl}-}-\overline{\mathrm{x}}\right)+\mathrm{b}_{2}\left(\mathrm{x}_{\mathrm{ijkl}}-\overline{\mathrm{x}}\right)+\mathrm{e}_{\mathrm{ijkl}}$

$\mathrm{Y}_{\mathrm{ijkl}}=$ Daily milk yield, milk fat ratio and rectal temperature, $\mu=$ average of the population,

$a_{i}=$ The effect of $i$. month

$b_{j}=$ The effect of $j$. lactation period, 
$b_{1}=$ regression coefficient of milk yield and milk fat ratio according to temperature humidity index values during milking,

$\mathrm{b}_{2}=$ regression coefficient of milk yield and milk fat ratio according to rectal temperature,

$\mathrm{x}_{\mathrm{ijkl}}=$ temperature humidity index value and rectal temperature,

$\overline{\mathrm{x}}=$ average temperature humidity index value and rectal temperature,

$\mathrm{e}_{\mathrm{ijklm}}=$ error.

When the rectal temperature is dependent variable, rectal temperature has not evaluated as a independent varible. The most likelihood method was used to obtain model estimates. However, the mean of the least squares for the temperature humidity index at milking point was obtained for each dependent variable. Pearson's correlation coefficients were used in order to determine the relationships between the variables in the continuous structure used in the study and regression models were created between the features whose relationship was significant. In addition, the mean, standard deviation, minimum and maximum values and $95 \%$ confidence limits for the mean variables are given as descriptive statistics. SAS 9.4 software was used for the statistical evaluation of the data. Proc Means, Proc Corr and Proc Mixed commands were used to perform analysis. Also, some regression models were constituted between the milk yield, rectal temperature, temperature humidity index and milk fat ratio.

\section{Results and Discussion}

Temperature, humidity and temperature humidity index values obtained during milking and in the shelter are given in Table 2. The highest temperature $\left(41{ }^{\circ} \mathrm{C}\right)$ was observed in the shelter in August and September, while the lowest temperature $\left(6.7^{\circ} \mathrm{C}\right)$ was detected in April. The highest humidity was experienced in May $(90.1 \%)$ and the lowest humidity (6.30\%) in September. The highest and lowest temperature humidity index values were observed in August (83.36) and April (46.07), respectively. The lowest $\left(11.5^{\circ} \mathrm{C}\right)$ and the highest $\left(30^{\circ} \mathrm{C}\right)$ temperatures during milking were observed in March and August, respectively. The lowest $(46 \%)$ and highest $(75 \%)$ humidity rates were observed in July and May, respectively. However, the lowest (53.54) and highest (77.97) temperature humidity index values were found to occur in March and August, respectively.

Temperature humidity index values obtained from the shelter were found to be higher than the threshold values reported in some previous studies (Vitali et al 2009; Collier et al 2011; Bouraoui et al 2002; Bernabucci et al 2010; De Rensis et al 2015). Although the temperature humidity index values during milking were found several units higher than inside the shelter, it was observed that the temperature humidity index values reached 83.56 , 82.96 etc. in some days in the shelter. It has been determined that dairy cattle are exposed to heat stress from the middle of May to the end of September in the current farm. In other words, the farm experiences about 5.5 months of heat stress within a year. This shows that the region has a warm climate. The use of fan and wetting methods, semi-open shelters and canopies in the farms ensures that the temperature and humidity index values decrease. It is estimated that cattle are exposed to heat stress for a long time and their productivity decreases in the Southeastern Anatolia Region where these methods are used almost negligibly.

In the current study, the rectal temperatures of cattle ranged from $35.6{ }^{\circ} \mathrm{C}$ (May) to the highest between $39.65{ }^{\circ} \mathrm{C}$ (August) between March and September. According to the monthly average values, the rectal temperatures of the cattle were determined the lowest in May $\left(36.89{ }^{\circ} \mathrm{C}\right)$ and the highest in August $\left(38.48{ }^{\circ} \mathrm{C}\right.$ ) (Table 3). A positive correlation was found between temperature humidity index and rectal temperatures of cattle ( $\mathrm{P}$ $<0.0001)$. Rectal temperatures of cattle reached their highest values in August, when temperatures increased. In the current study, a negative relationship was determined between rectal temperature and milk yield $(\mathrm{P}<0.01)$. Heat stress causes the rectal temperatures in cattle to increase and thus to decrease milk yield. The negative relationship between rectal temperature and milk yield determined in this study is in agreement with (Nardone et al

2006)

Table 2

Temperature, humidity and temperature-humidity index values in the farm and during milking

\begin{tabular}{lllllll}
\hline Months & Values & MAT & MAH & MATHI & MPT & MPH \\
\hline \multirow{4}{*}{ March } & Mean & $13.95 \pm 1.91$ & $61.45 \pm 6.41$ & $57.27 \pm 2.71$ & 11.50 & 71.00 \\
& Sample number & 6 & 6 & 6 & & \\
& Minimum & 11.80 & 52.80 & 54.08 & & \\
& Maximum & 16.10 & 67.90 & 60.39 & & \\
\multirow{3}{*}{ April } & Mean & $14.95 \pm 3.90$ & $69.17 \pm 13.65$ & $58.64 \pm 5.69$ & 21.00 & 68.00 \\
& Sample number & 360 & 360 & 360 & & \\
& Minimum & 6.70 & 31.60 & 46.07 & & \\
& Maximum & 26.40 & 89.60 & 73.89 & & \\
\hline
\end{tabular}


Table 2

Temperature, humidity and temperature-humidity index values in the farm and during milking

\begin{tabular}{|c|c|c|c|c|c|c|c|}
\hline \multirow{4}{*}{ May } & Mean & $19.83 \pm 4.61$ & $63.33 \pm 16.47$ & $65.11 \pm 5.78$ & 19.00 & 75.00 & 65.05 \\
\hline & Sample number & 373 & 373 & 373 & & & \\
\hline & Minimum & 9.20 & 20.80 & 49.70 & & & \\
\hline & Maximum & 30.60 & 90.10 & 76.97 & & & \\
\hline \multirow{4}{*}{ June } & Mean & $24.11 \pm 6.17$ & $47.63 \pm 19.04$ & $69.19 \pm 6.21$ & 25.50 & 47.50 & 72.07 \\
\hline & Sample number & 336 & 336 & 336 & & & \\
\hline & Minimum & 11.50 & 13.80 & 53.18 & & & \\
\hline & Maximum & 36.60 & 87.90 & 79.09 & & & \\
\hline \multirow{4}{*}{ July } & Mean & $29.78 \pm 6.33$ & $31.56 \pm 13.25$ & $74.29 \pm 5.34$ & 30.00 & 46.00 & 77.58 \\
\hline & Sample number & 385 & 385 & 385 & & & \\
\hline & Minimum & 17.10 & 8.70 & 61.78 & & & \\
\hline & Maximum & 40.30 & 67.60 & 82.96 & & & \\
\hline \multirow{4}{*}{ August } & Mean & $30.42 \pm 6.57$ & $29.20 \pm 13.06$ & $74.61 \pm 5.37$ & 30.00 & 48.50 & 77.97 \\
\hline & Sample number & 228 & 228 & 228 & & & \\
\hline & Minimum & 18.60 & 7.40 & 63.17 & & & \\
\hline & Maximum & 41.00 & 56.50 & 83.36 & & & \\
\hline \multirow{4}{*}{ September } & Mean & $28.11 \pm 6.61$ & $30.03 \pm 11.99$ & $72.33 \pm 5.96$ & 26.00 & 52.00 & 73.23 \\
\hline & Sample number & 504 & 504 & 504 & & & \\
\hline & Minimum & 14.30 & 6.30 & 57.80 & & & \\
\hline & Maximum & 41.00 & 56.80 & 82.30 & & & \\
\hline \multirow{4}{*}{ Total } & Mean & $24.42 \pm 8.00$ & $45.09 \pm 21.86$ & $68.91 \pm 8.02$ & $23.28 \pm 6.65$ & $58.29 \pm 12.50$ & $69.59 \pm 8.52$ \\
\hline & Sample number & 2192 & 2192 & 2192 & 7 & 7 & 7 \\
\hline & Minimum & 6.70 & 6.30 & 46.07 & 11.50 & 46.00 & 53.54 \\
\hline & Maximum & 41.00 & 90.10 & 83.36 & 30.00 & 75.00 & 77.97 \\
\hline
\end{tabular}

MAT: Monthly average temperature, MAH: Monthly average humidity, MATHI: Monthly average temperature-humidity index, MPT: Milking parlor temperature, MPH: Milking parlor humidity, MPTHI: Milking parlor temperature-humidity index

During the study, the highest $(41.7 \mathrm{~kg})$ and the lowest $(8.4 \mathrm{~kg})$ daily milk yield was obtained in April, while the average milk yield was determined as $24.39 \mathrm{~kg}$. It was determined that milk yield decreased in the summer months from May to September (Table 3). A significant negative correlation was found between milk yield and temperature humidity index $(\mathrm{P}<0.05)$ and rectal temperature $(\mathrm{P}<0.01)$. In accordance with this study, it has been reported that heat stress reduces milk yield in different studies (Brouček et al 2009; Brown et al 2015; Al Reyad et al 2016; Gaafar et al 2011; Nardone et al 2006).

The lowest (2.40\%) and highest (7.35\%) milk fat ratio was obtained in September and April, respectively. A significant negative correlation was found between temperature, humidity index value and milk fat ratio $(\mathrm{P}<0.01)$. In different studies, it was determined that heat stress caused a decrease in milk fat ratio (Bouraoui et al 2002; JoksimovićTodorovićet al 2011; Gorniak et al, 2014; Tuyttens et al 2015) and it was found similar to this study.

Regression models between temperature humidity index and rectal temperature, milk yield and milk fat ratio and between milk yield and rectal temperature are as follows;

Table 3
1. $\mathrm{RT}($ Rectal temperature $)=33.480+(0.063 \times \mathrm{THI})$

2. MY1 (Milk yield-1) $=43.104+(-0.263 \times \mathrm{THI})$

3. MFR (Milk fat ratio) $=7.001+(-0.044 \times \mathrm{THI})$

4. MY2 (Milk yield-2) $=132.843+(-2.855 \times$ RT $)$

As the temperature humidity index increases, the rectal temperature of the cattle increases, the milk yield and the milk fat ratio decrease. According to the regression models, for example, while milking temperature humidity index values are $65,69,73$ and 80 , the rectal temperatures of the cattle are $37.58{ }^{\circ} \mathrm{C}, 37.83{ }^{\circ} \mathrm{C}, 38.08{ }^{\circ} \mathrm{C}$ and 38.52 ${ }^{\circ} \mathrm{C}$, milk yields $26.01 \mathrm{~kg}, 24.96 \mathrm{~kg}, 23.91 \mathrm{~kg}$ and $22.06 \mathrm{~kg}$ and milk fat rates were found as $4.14 \%$, $3.97 \%, 3.79 \%$ and $3.48 \%$.However, according to the regression model between rectal temperature and milk yield, the rectal temperature was $37.58^{\circ} \mathrm{C}$, $37.83{ }^{\circ} \mathrm{C}, 38.08{ }^{\circ} \mathrm{C}$ and $38.52{ }^{\circ} \mathrm{C}$, while milk yield was $25.57 \mathrm{~kg}, 24.85 \mathrm{~kg}, 24.13 \mathrm{~kg}$ and $22.87 \mathrm{~kg}$. In other words, when the temperature humidity index value is less than 71, milk yield is more affected by the increased rectal temperature, and when it is more than 71 , it is observed that there is more decrease in milk yield due to the increasing temperature humidity index value. As it continues to rise, it can be interpreted that it is more effective in the beginning when the body temperatures rise faster.

Monthly average rectal temperature, milk yield and milk fat ratio values

\begin{tabular}{lllll}
\hline Months & & Rectal temperature $\left({ }^{\circ} \mathrm{C}\right)$ & Milk yield $(\mathrm{kg})$ & Milk fat $(\%)$ \\
\hline \multirow{4}{*}{ March } & Mean & $37.25 \pm 0.71$ & $26.88 \pm 8.80$ & $5.09 \pm 0.32$ \\
& Animal number & 5 & 4 & 4 \\
& Minimum & 36.40 & 14.70 & 4.75 \\
& Maximum & 37.95 & 35.40 & 5.45 \\
\hline
\end{tabular}


Table 3

Monthly average rectal temperature, milk yield and milk fat ratio values

\begin{tabular}{|c|c|c|c|c|}
\hline \multirow{4}{*}{ April } & Mean & $38.35 \pm 0.45$ & $24.72 \pm 11.21$ & $4.63 \pm 1.35$ \\
\hline & Animal number & 13 & 13 & 12 \\
\hline & Minimum & 37.15 & 8.40 & 2.75 \\
\hline & Maximum & 38.80 & 41.70 & 7.35 \\
\hline \multirow{4}{*}{ May } & Mean & $36.89 \pm 0.68$ & $28.06 \pm 7.47$ & $3.44 \pm 0.56$ \\
\hline & Animal number & 13 & 13 & 13 \\
\hline & Minimum & 35.60 & 11.40 & 2.55 \\
\hline & Maximum & 37.90 & 40.55 & 4.25 \\
\hline \multirow{4}{*}{ June } & Mean & $37.90 \pm 0.44$ & $26.38 \pm 5.56$ & $3.69 \pm 0.64$ \\
\hline & Animal number & 13 & 13 & 13 \\
\hline & Minimum & 36.85 & 18.58 & 2.45 \\
\hline & Maximum & 38.55 & 34.30 & 4.60 \\
\hline \multirow{4}{*}{ July } & Mean & $38.35 \pm 0.46$ & $24.63 \pm 5.30$ & $3.42 \pm 0.57$ \\
\hline & Animal number & 12 & 12 & 12 \\
\hline & Minimum & 37.65 & 15.43 & 2.45 \\
\hline & Maximum & 39.20 & 31.30 & 4.25 \\
\hline \multirow{4}{*}{ August } & Mean & $38.48 \pm 0.44$ & $21.54 \pm 3.49$ & $3.68 \pm 0.57$ \\
\hline & Animal number & 13 & 12 & 13 \\
\hline & Minimum & 37.80 & 15.74 & 2.85 \\
\hline & Maximum & 39.65 & 27.90 & 4.60 \\
\hline \multirow{4}{*}{ September } & Mean & $38.23 \pm 0.35$ & $20.07 \pm 4.22$ & $4.01 \pm 0.78$ \\
\hline & Animal number & 13 & 13 & 13 \\
\hline & Minimum & 37.75 & 12.40 & 2.40 \\
\hline & Maximum & 38.80 & 26.20 & 5.60 \\
\hline \multirow{5}{*}{ Total } & Mean & $37.98 \pm 0.74$ & $24.39 \pm 7.14$ & $3.87 \pm 0.89$ \\
\hline & Animal number & 82 & 80 & 80 \\
\hline & Minimum & 35.60 & 8.40 & 2.40 \\
\hline & Maximum & 39.65 & 41.70 & 7.35 \\
\hline & $\mathrm{R}^{2}$ & & 0.354 & 0.182 \\
\hline
\end{tabular}

\section{Conclusion}

As a result, it was determined that the rectal temperature increases with the heat stress and milk yield decreases and cooling systems should be used to eliminate these negativities. It has been determined that cattle are exposed to heat stress from mid-May to mid-September, although the current farm is half open and the farm uses 2 fans to cool during milking. It is understood that the cooling system used here is insufficient. Considering this dairy cattle farm, it is considered that more effective fans and wetting methods should be used for cooling the animals in the dairy cattle farms in Siirt province and Southeast Anatolia region where the temperatures are high. In addition, it is expected that artificial shades and afforestation in pastures will be beneficial in reducing heat stress.

\section{References}

Al Reyad M, Sarker MAH, Uddin ME, Habib R, Rashid MHU (2016). Effect of heat stress on milk production and its composition of Holstein Friesian crossbred dairy cows. Asian Journal of Medical and Biological Research 2(2): 190195.
Arieli A, Adin G, Bruckental I (2004). The effect of protein intake on performance of cows in hot environmental temperatures. Journal of dairy science 87(3): 620-629.

Baumgard LH, Rhoads RP, Rhoads ML, Gabler NK, Ross JW, Keating AF, ... Sejian V (2012). Impact of climate change on livestock production. In Environmental stress and amelioration in livestock production (pp. 413468). Springer, Berlin, Heidelberg.

Bernabucci U, Lacetera N, Baumgard LH, Rhoads RP, Ronchi B, Nardone A (2010). Metabolic and hormonal acclimation to heat stress in domesticated ruminants. Animal 4(7): $1167-$ 1183.

Bouraoui R, Lahmar M, Majdoub A, Belyea R (2002). The relationship of temperaturehumidity index with milk production of dairy cows in a Mediterranean climate. Animal Research 51(6): 479-491.

Brouček J, Pavel N, Vokřálová J, Šoch M, Kišac P, Uhrinčat' M (2009). Effect of high temperature on milk production of cows from free-stall housing with natural ventilation. Slovak Journal of Animal Science 42(4): 167-173. 
Brown BM, Stallings JW, Clay JS, Rhoads ML (2015). Periconceptional heat stress of holstein dams is associated with differences in daughter milk production and composition during multiple Lactations. Plos One 10(10): $\mathrm{e} 0133574$

Collier RJ, Zimbelman RB, Rhoads RP, Rhoads ML, Baumgard LH (2011). A re-evaluation of the impact of temperature humidity index (THI) and black globe humidity index (BGHI) on milk production in high producing dairy cows. In Western Dairy Management Conf. Reno, $N V$. USA (pp. 113-125).

De Rensis F, Garcia-Ispierto I, López-Gatius F (2015). Seasonal heat stress: Clinical implications and hormone treatments for the fertility of dairy cows. Theriogenology 84(5): 659-666.

El-Wishy AB (2013). Fertility of Holstein cattle in a subtropical climate of Egypt. Iranian Journal of Applied Animal Science 3(1): 45-51.5

Evans AC, Walsh SW (2011). The physiology of multifactorial problems limiting the establishment of pregnancy in dairy cattle. Reproduction, Fertility and development 24(1): 233-237.

Gaafar HMA, Gendy ME, Bassiouni MI, Shamiah SM, Halawa AA, Hamd MA (2011). Effect of heat stress on performance of dairy Friesian cow's milk production and composition. Researcher 3(5): 85-93.

Ghavi Hossein-Zadeh N, Mohit A, Azad N (2013). Effect of temperature-humidity index on productive and reproductive performances of Iranian Holstein cows. Iranian Journal of Veterinary Research 14(2): 106-112.

Gorniak T, Meyer U, Südekum KH, Dänicke S (2014). Impact of mild heat stress on dry matter intake, milk yield and milk composition in midlactation Holstein dairy cows in a temperate climate. Archives of animal nutrition 68(5): 358-369.

Hekimoğlu B, Altındeğer M (2008). Ülkemizde ve Samsun ilinde; süt hayvancılığı ve süt sektöründeki mevcut durum sorunlar ve öneriler. Samsun İl Tarım Müdürlüğü, Samsun.

Joksimović-Todorović M, Davidović V, Hristov S, Stanković B (2011). Effect of heat stress on milk production in dairy cows. Biotechnology in Animal Husbandry 27(3): 1017-1023.

Khodaei-Motlagh M, Shahneh AZ, Masoumi R, Derensis F (2011). Alterations in reproductive hormones during heat stress in dairy cattle. African Journal of Biotechnology 10(29): 5552-5558.
Mader TL, Davis MS, Brown-Brandl T (2006). Environmental factors influencing heat stress in feedlot cattle. Journal of Animal Science 84(3): 712-719.

Mutaf S, Sönmez R (1984). Hayvan barınaklarında iklimsel çevre ve denetimi. Ege Üniversitesi Ziraat Fakültesi Yayınları, İzmir.

Nardone A, Ronchi B, Lacetera N, Bernabucci U (2006). Climatic effects on productive traits in livestock. Veterinary Res. Communication, 30(1): 75-81.

Öten M, Işık M, Çetinkaya M (2010). Feeding dairy cattle in hot weather conditions. Atatürk Üniversitesi Ziraat Fakültesi Dergisi 353(4): 229-234.

Rejeb M, Najar T, M'Rad MB (2012). The effect of heat stress on dairy cow's performance and animal behaviour. IJAPES 2(3): 29-34.

Thom EC (1959). The discomfort index. Weatherwise 12(2): 57-61.

Trajchev M, Nakov D, Andonov S (2016). The effect of thermal environment on daily milk yield of dairy cows. Macedonian Veterinary Review 39(2): 185-192.

Tuncel E (1994). Hayvan 1slahı. Uludağ Üniversitesi Ziraat Fakültesi Ders Notları, Bursa.

Tuyttens FAM, Ampe B, Sonck B, Moons CPH, Vandaele L (2015). Effect of summer conditions and shade on the production and metabolism of Holstein dairy cows on pasture in temperate climate. Animal 9(9): 1547-1558.

Vitali A, Segnalini M, Bertocchi L, Bernabucci U, Nardone A, Lacetera N (2009). Seasonal pattern of mortality and relationships between mortality and temperature-humidity index in dairy cows. Journal of Dairy Science 92(8): 37813790 .

West JW (1999). Nutritional strategies for managing the heat-stressed dairy cow. Journal of Animal Science 77(2): 21-35.

West JW, Mullinix BG, Bernard JK (2003). Effects of hot, humid weather on milk temperature, dry matter intake, and milk yield of lactating dairy cows. Journal of Dairy Science 86(1): 232-242.

Zhu W, Zhang BX, Yao KY, Yoon I, Chung YH, Wang JK, Liu JX (2016). Effects of supplemental levels of Saccharomyces cerevisiae fermentation product on lactation performance in dairy cows under heat stress. Asian-Australasian journal of animal sciences 29(6): 801-806. 